\title{
Comparison of DNA extraction methods for molecular identification of pathogenic Leptospira in the urine samples
}

DOI: https:// doi.org/10.22435/hsji.v11i2.3749

Farida Dwi Handayani ${ }^{1}$, Rahmi Ayu Wijayaningih ${ }^{2}$, Ristiyanto ${ }^{1}$, Muhammad Hussein Gasem ${ }^{3}$, Tri Wibawa ${ }^{4}$

${ }^{1}$ Institute for Vector and Reservoir Control Research and Development, National Institute of Health Research and Development, Ministry of Health Republic of Indonesia

${ }^{2}$ Master in Biomedical Science, Faculty of Medicine, Public Health and Nursing, Gadjah Mada University, Yogyakarta, Indonesia

${ }^{3}$ Dr. Kariadi Hospital, Semarang, Indonesia / Center for Tropical and Infectious Diseases, Faculty of Medicine, Diponegoro University, Semarang, Indonesia

${ }^{4}$ Department of Microbiology, Faculty of Medicine, Public Health and Nursing, Gadjah Mada University, Yogyakarta, Indonesia

Corresponding author: Farida D Handayani

Email: farida.litbangkes@gmail.com

Received: August 29, 2020; Revised: September 30, 2020; Accepted: November 9, 2020

\begin{abstract}
Abstrak
Latar belakang: Leptospirosis merupakan zoonosis penting di dunia, yang masih sering terjadi salah diagnosis. Deteksi laboratorium Leptospira menjadi tantangan karena bakterimea cukup singkat untuk dideteksi molekuler, namun antibodi juga muncul sangat lambat. Urine dapat menjadi sampel alternatif untuk deteksi PCR pada leptospirosis. Pengerjaan PCR membutuhkan DNA berkualitas dan andal, dan diperoleh dari metode ekstraksi DNA yang baik. Penelitian bertujuan untuk mengetahui metode ekstraksi DNA Leptospira terbaik untuk sampel urin, serta mengevaluasi pengaruh waktu penyimpanan dan suhu terhadap kestabilan DNA.
\end{abstract}

Metode: Penelitian ini menggunakan tiga metode isolasi DNA yang berbeda; berbasis silika dengan spin kolom, kromatografi spin column menggunakan resin sebagai matriks pemisah, dan metode larutan dengan guanidine isothiocyanate. Hasil ekstraksi diperiksa konsentrasi dan kemurniannya. Gen SecY pada Leptospira dideteksi dengan PCR real-time. Pengaruh suhu dan lama penyimpanan DNA juga dilihat.

Hasil: Hasil isolasi DNA menggunakan resin menunjukkan konsentrasi tertinggi $(7,94+2,11 \mu \mathrm{g} / \mathrm{mL})$ dan jumlah salinan amplifikasi DNA Leptospira tertinggi $(50167,92+1,19)$. Suhu penyimpanan pada suhu $4^{\circ} \mathrm{C},-20^{\circ} \mathrm{C}$, dan $-80^{\circ} \mathrm{C}$ dan umur simpan 91 hari tidak berpengaruh terhadap kualitas dan kuantitas DNA Leptospira hasil isolasi spike urin.

Kesimpulan: Isolasi DNA menggunakan spin column chromatography dengan resin sebagai matriks separasi memiliki kualitas dan kuantitas terbaik berdasarkan kemurnian dan konsentrasi DNA serta jumlah gen SecY yang teramplifikasi. (Health Science Journal of Indonesia 2020;11(2):77-84)

Kata kunci: Leptospira, Leptospirosis, ekstraksi DNA, sampel urin, penyimpanan sampel.

\begin{abstract}
Background: Leptospirosis is a worldwide zoonotic disease, which is still often misdiagnosed. Laboratory detection of Leptospira is challenging since the bacteraemia is quite short for molecular detection, however, the rise of the antibody is late to post the infection. Urine can be a potential alternative sample for PCR detection in leptospirosis. The PCR method requires a reliable DNA template, which is obtained from good DNA extracting methods. The study aimed to determine the best method of extraction Leptospira DNA from the urine sample, as well as evaluating the effect of time storage and temperature for its DNA stability.

Methods: This study was utilizing three different DNA isolation methods; silica based with spin column, spin column chromatography using resin as separation matrix, and solution method with guanidine isothiocyanate. The yields were examined for its concentration and purity. Leptospira's SecY gene was detected with realtime PCR. The influences of storage temperature and the life time of the DNA were also studied.

Results: The yield of DNA isolation using resin showed the highest concentration $(7.94 \pm 2.11 \mu \mathrm{g} / \mathrm{mL})$ and highest Leptospira DNA amplification copy number (50167.92 \pm 1.19$)$. Storage temperature at $4{ }^{\circ} \mathrm{C},-20^{\circ} \mathrm{C}$, and $-80^{\circ} \mathrm{C}$ and life time of 91 days did not have any effect on the quality and quantity of Leptospira DNA isolated from spiked urine.

Conclusions: DNA isolation using spin column chromatography with resin as separation matrix has the best quality and quantity based on the purity and concentration of DNA and the higher number of amplified SecY gene. (Health Science Journal of Indonesia 2020;11(2):77-84)
\end{abstract}

Keywords: Leptospira, Leptospirosis, DNA extraction, urine sample, sample storage. 
Leptospirosis is a worldwide zoonosis and endemic in South East Asia. The disease can cause severe infection in humans. The infectious disease is caused by pathogenic bacteria, Leptospira interrogans. ${ }^{1}$ In Indonesia, the case fatality rate of leptospirosis is reportedly high and the incidence rate is still uncertain and often under-reported. The mortality and morbidity of the disease are high, however, difficult to predict due to mis-diagnosis. ${ }^{2}$ The clinical manifestation of the disease ranges from asymptomatic to severe disease with rapid mortality. It is difficult to differentiate leptospirosis from other diseases that have similar symptoms including fever, headache and myalgia such as dengue, malaria and influenza. A severe manifestation of leptospirosis (Weil's disease), is characterized by fever, jaundice, renal failure and haemorrhage. ${ }^{3}$

There are several methods available to diagnose leptospirosis. Polymerase chain reaction (PCR) is one of the diagnostic methods that has been reported to be able to detect pathogenic Leptospira from clinical samples such as blood, urine, cerebrospinal fluid and infected organs. It is also a sensitive, specific and rapid technique ${ }^{4}$, but the sensitivity and results of PCR reaction also depend on the quality of isolated DNA because only a small amount of the original sample is included in the final PCR assay. ${ }^{5,6}$ The DNA extraction is included as Nucleic Acid Extraction (NAE) methods can be more broadly characterized to be solid-phase or chemically actuated methods. ${ }^{7}$

Blood, cerebrospinal fluid (CSF) and urine have been known as specimens for Leptospira DNA detection. Leptospira's DNA can be found in the blood 48 hours after infection. Meanwhile, CSF could be used to detect Leptospira within the first week of illness. The detection of Leptospira in the urine can be done from the early course of the disease before the initiation of antimicrobial therapy ${ }^{1}$ the brown rat (Rattus norvegicus. The urine as specimen has advantages over the others. However, urine also has some disadvantages as a DNA isolation specimen. Urine contains factors that inhibit DNA amplification such as urea and nitrite. ${ }^{8}$ The other disadvantage is because the bacteria contained in it produce endonuclease which breaks down the DNA. ${ }^{8,9}$

Spiked urine was produced from healthy urine contaminated with certain bacteria. This procedure is performed to make a model for experimental study such as the detection of bacteria in urine and comparison study of urine DNA isolation. ${ }^{10-12}$ DNA isolation could be obtained through several ways and currently DNA isolation kits provide different choices of samples, which cover both specific and non-specific specimens including kits for tissue, blood, and urine. ${ }^{9}$

Storage conditions can affect DNA quality and quantity. Degradation of DNA in storage can influence molecular biology testing. One problem is temperature fluctuations over time. Temperatures at $4^{\circ} \mathrm{C},-20^{\circ} \mathrm{C}$ or $-80^{\circ} \mathrm{C}$ are reported to be good conditions for DNA storage. ${ }^{13,14}$

Blood and urine samples may serve as reliable specimens; however, urine has advantages since it does not require intervention in the collection process and it contains fewer biological units, therefore it is simpler to be tested. Producing a reliable PCR product means good preparation is required to produce an excellent DNA template. The outstanding quality of the DNA templates can only be achieved through a reliable process of DNA isolation with good storage conditions. A good DNA template is produced from a reliable isolation DNA process. A reliable isolation method and good storage conditions are supposed to be able to produce good DNA isolated product, but unfortunately to this date the method to properly isolate DNA of Leptospira from urine and the best storage conditions have not been well established.

This study aimed to determine the best DNA isolation method that produces good quality and quantity of DNA from Leptospira spiked urine and also determine the effect of temperature and shelf life.

\section{METHODS}

This study is classified as an analytical study to compare three methods to isolate leptospira DNA from urine samples. The study was conducted from May 2018 to October 2018 at the Institute for Vector and Reservoir Control Research and Development (B2P2VRP), Salatiga, Indonesia. The urine samples were collected from 5 healthy volunteers, who do not have any degeneration diseases and not taking any medicine or food supplements two days before the samples were taken. The urine sample criteria were the second urination in the morning. All the volunteers have signed informed consent before the study. The total numbers of replication attempts were 4 times. Accordingly, the total numbers of the samples were twenty $(\mathrm{N}=20)$. 
The urine samples were used as media for the spike process. The culture of the pathogenic Leptospira serovar Icterrohaemorrhagie, which is maintained at Bacteriology Laboratory, Institute for Vector and Reservoir Control Research and Development (IVRCRD) Salatiga with a concentration of $2 \times 10^{8}$ $\mathrm{CFU} / \mathrm{mL}$ was inactivated at $50^{\circ} \mathrm{C}$. The culture was diluted using Phosphate Buffer Saline (PBS) until its concentration became $1 \times 10^{8} \mathrm{CFU} / \mathrm{mL}$. Then the culture was gradually diluted with the urine until the concentration reached $1 \times 10^{6} \mathrm{CFU} / \mathrm{mL}$ as the working concentration. Accordingly, the 5 urine samples (from 5 volunteers) were aliquoted into 4 tubes. Each tube received 1 million CFU of the bacteria and was stored in $\left(-20^{\circ} \mathrm{C}\right)$ freezer for a future experiment.

All the DNA extraction steps and the qPCR tests in this study were performed by one student. Our technicians assisted her only in preparing the serovar (Icterrohaemorrhagie) to be spiked in the urine samples.

\section{DNA isolation from spiked urine}

All the urine samples were taken from $-20^{\circ} \mathrm{C}$ freezer were thawed completely in the ice cubes to let it thaw gradually and avoid the shock heat. The samples then underwent well vortex before the extraction process, as follows:

\section{The silica-based with spin column}

The urine samples were centrifuged at 14,000 $\mathrm{g}$ for 3 minutes. The supernatant was then removed and the pellet was extracted following the protocol from DNA isolation kit by Thermo Fisher Scientific (PureLink ${ }^{\mathrm{TM}}$ Genomic DNA Mini Kit catalogue number K1820-01).

2. The spin column chromatography using resin as the separation matrix

The $1.75 \mathrm{ml}$ of urine was adding with $0.25 \mathrm{ml}$ of the binding solution and centrifuged for 1 minute at $6700 \mathrm{~g}$ and then continued by following the protocol from Norgen's Urin DNA isolation kit (urine DNA isolation Kit product \# 18100).

3. The guanidine isothiocyanate DNA isolation method The urine samples as much as $1 \mathrm{ml}$ was centrifuged at $14,000 \mathrm{~g}$ for 3 minutes. The supernatant was discarded and the pellet was taken to be followed by the protocol of TRIzol TM Reagent (catalogue number 15596026).

We checked the $\mathrm{pH}$ qualitatively using $\mathrm{pH}$ paper Merck Universal $\mathrm{pH} 0-14$. All the urine samples were in normal $\mathrm{pH}$ (6-7).

\section{Storage time and temperature}

DNA extracted from urine samples were aliquoted and storage into three different temperatures: $-80^{\circ} \mathrm{C},-20^{\circ} \mathrm{C}$, and $4^{\circ} \mathrm{C}$. The DNA template also was analyzed every 2 weeks, during 3 months of observation. We did not find any crystal on the samples during cold storage.

\section{Concentration and purity}

The DNA concentration $(\mu \mathrm{g} / \mathrm{mL})$ and purity (absorbance ratio at A260/A280) were determined by spectrophotometry using the NanoDrop 2000 (Thermo Fisher Scientific, Waltham, MA, USA).

\section{Leptospira DNA amplification}

The presence of Leptospira DNA was detected using a real time PCR (qPCR) assay, with amplifying $\mathrm{Sec} Y$ gene as the housekeeping gene, specific for Leptospira. The $\operatorname{Sec} Y$ gene correspond to primer sequences were R- CCGTCCCTTAATTTTAGACTTCTTC and FATGCCGATCATTTTTGCTTC..$^{15}$ The master mix was prepared in BSC/PCR work station with composition: $5 \mu \mathrm{L}$ Ssofast ${ }^{\mathrm{TM}}$ Eva Green ${ }^{\circledR}$ Super mixes, $1 \mu \mathrm{L}$ forward sec $Y$ Primer, $1 \mu \mathrm{L}$ reverse $\mathrm{Sec} Y$ Primer, $2 \mu \mathrm{L}$ dd $\mathrm{H} 2 \mathrm{O}$, and $1 \mu \mathrm{L}$ DNA template. The solution was processed in a regulated PCR machine: pre-denaturation $98^{\circ} \mathrm{C}$ for 2 minutes, denaturation $95^{\circ} \mathrm{C}$ for 30 seconds, annealing $60^{\circ} \mathrm{C}$ for 30 seconds, extension $65^{\circ} \mathrm{C}$ for 5 second. The qPCR cycle was set to 40 times.

A standard curve was made using a known concentration of Leptospira DNA. Serial dilutions were performed, starting from $10^{\circ}$ until $10^{7}$ of LeptospiraDNA copy. In parallel, the Real Time PCR was performed in duplicates. The calculation of regression was obtained from the serial dilution result. The quantification data of Leptospira DNA were calculated by using the regression equation:

$$
10^{(\mathrm{cq}-\mathrm{b} / \mathrm{r})}
$$

where $\mathrm{Cq}=$ cycle of amplification, $\mathrm{b}=\mathrm{y}$ intercept, $\mathrm{r}=$ regression coefficient.

\section{Statistical analysis}

The variances between DNA isolation results and differences in storage temperature and time were statistically analyzed using ANOVA Tukey's multiple comparison tests. Prior to the ANOVA analysis, the data, which were presented as mean for each group, were checked for its' distribution normality. The software used for statistical analysis in this study was SPSS version 10 and the cut-off value for the 
statistical significance was $p<0.01$. The reason was that the data obtained from the laboratory study with a high level of accuracy and the study was supported by sophisticated equipment.

\section{Ethical consideration}

This study protocol had been approved by the Health Research Ethics Committee, National Institute of Health Research and Development (HERC-NIHRD) no. LB.02.01/2/KE.268/2018.

\section{RESULTS}

\section{Total DNA concentration}

The total DNA concentration indicated the amount of DNA isolated from the specimen. The total DNA concentration is shown in Figure 1. There was no significant difference among the three methods $(p=$
0.897). However, DNA isolation using resin showed the highest average yield $(7.94 \pm 2.11 \mu \mathrm{g} / \mathrm{mL})$.

\section{DNA purity}

The purity of the DNA isolates was shown as a ratio of optical density (OD) at A260/280. The DNA purity of each method is shown in Table 1 . The results of DNA isolation using resin showed purity value in recommended range, DNA was considered in good purity when the value of A260/280 is 1.82.0 [7]. There was no significant difference between methods $(p=0.085)$

\section{The leptospira DNA amplification}

The data of DNA amplification showed that the isolation of DNA with resin has the highest amount of DNA copies $(50,167.92 \pm 1.19)$. The result showed a significant difference $(p=0.0025)$ between each isolation methods. The result of Leptospira DNA amplification is shown in Figure 2.

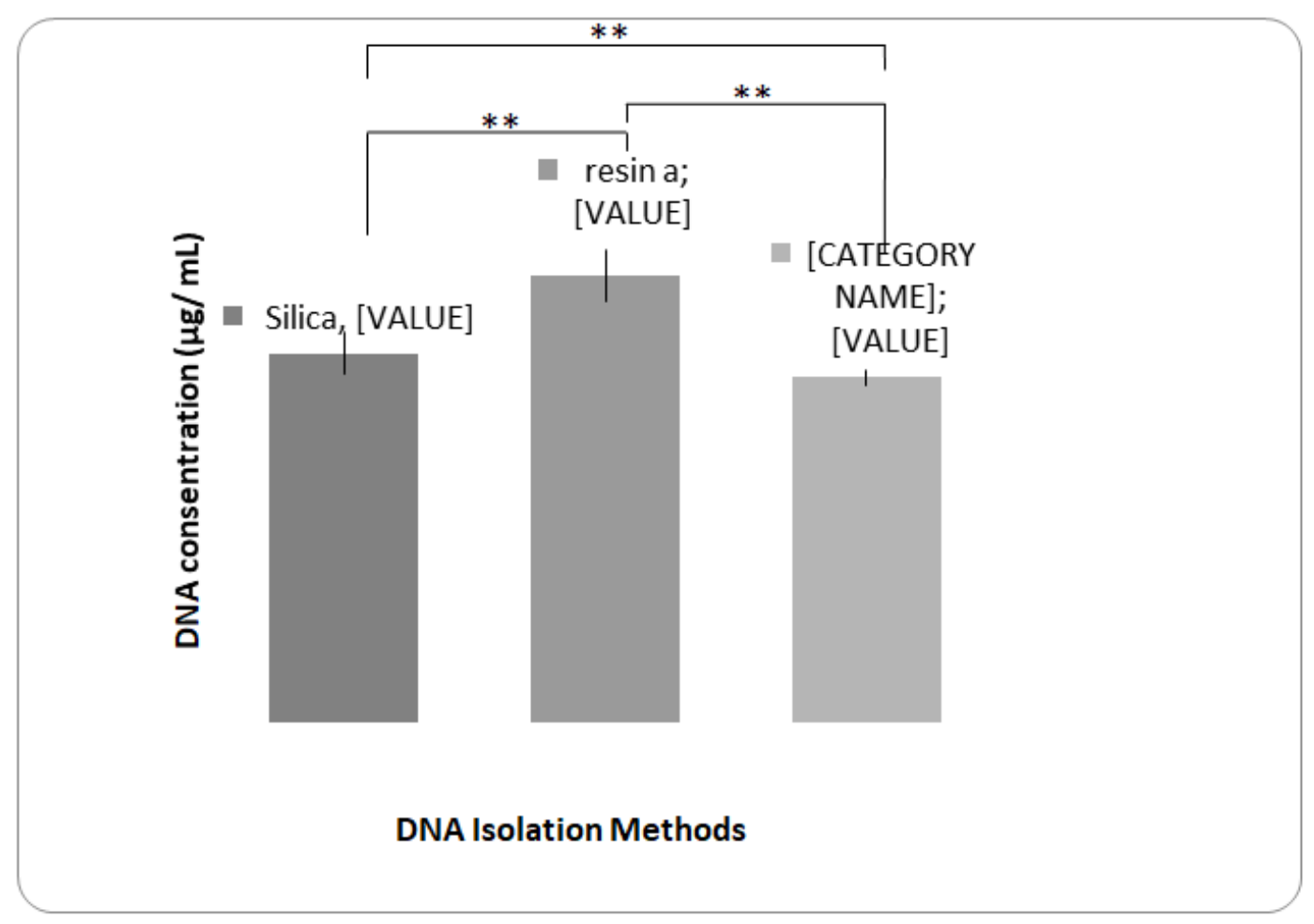

Figure 1. Total DNA concentration extracted by using three different methods: silica, resin a, and guanidine isolation. $p>0.01$ (one way anova followed by t test) $N=20$. **denoted: $p<0.01$ (one way anova followed by $t$ test). $N=20$. 


\section{Effect of storage temperature to the concentration of leptospira DNA}

The DNA concentration showed no significant changes over time. The different temperature storage also did not affect the DNA concentration. This result is indicated by the magnitude of the $p>0.01$ from day to day. DNA concentration at $-80^{\circ} \mathrm{C}(p=0.997),-20^{\circ} \mathrm{C}$ $(p=0.936)$ and $4^{\circ} \mathrm{C}(p=0.781)$ remained stable. The result of Leptospira DNA stability is shown in Table 2.

Table 1. Leptospira's DNA purity extracted by using three different methods $(p=0.085)$.

\begin{tabular}{lcc}
\hline \multicolumn{1}{c}{ Methods } & $\begin{array}{c}\text { Leptospira's DNA Purity } \\
\text { (mean) }\end{array}$ & SD \\
\hline Silica & 2.11 & 0.14 \\
resin & 1.57 & 0.66 \\
Guanidine & 2.63 & 0.23 \\
\hline
\end{tabular}

\section{Effect of storage temperature to the purity of} leptospira DNA

The different temperature storage was not affecting the DNA purity over the time significantly. This result is indicated by the magnitude of the $p$-value $>0.01$ from day to day. DNA concentration at $-80^{\circ} \mathrm{C}$ ( $p$-value 0.158$),-20^{\circ} \mathrm{C}$ ( $p$-value 0.035$)$ and $4^{\circ} \mathrm{C}$ ( $p$-value 0.356$)$ remained stable. Table 3 shows the stability of Leptospira DNA purity.

\section{Effect of storage to the yield of leptospira DNA amplification}

The variable storage temperature did not affect the result of DNA amplification (Table 4). DNA copy number after qPCR amplification using DNA template which were stored in different temperature at $-80^{\circ} \mathrm{C}$ ( $p$-value 0.894$),-20^{\circ} \mathrm{C}(p$-value 0.741$)$ and $4^{0} \mathrm{C}$ ( $p$-value 0.621 ) remained stable.

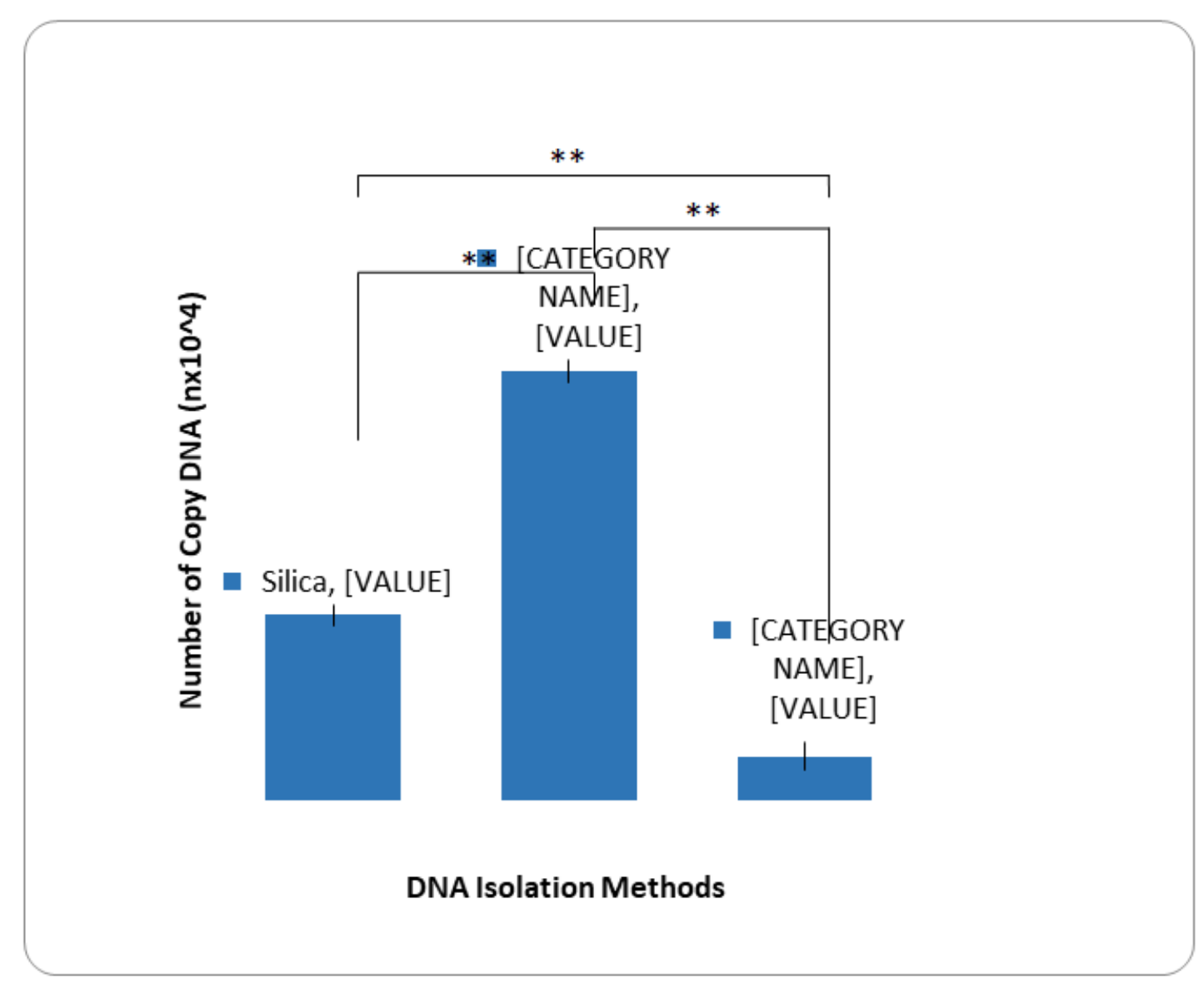

Figure 2. The Leptospira DNA copy number after real time PCR amplification assay of DNA extracted from three different methods: silica, resin a, and guanidine isolation. ** denoted: overall significant p value at 0.0025 (one way anova followed by t test). $N=20$. 
Table 2. Concentration of leptospira DNA stored in different temperatures

\begin{tabular}{|c|c|c|c|c|c|c|c|}
\hline \multirow{2}{*}{$\begin{array}{l}\text { Storage } \\
\text { temperature }\end{array}$} & Shelf life (Days) & 1 & 14 & 28 & 43 & 91 & \multirow[t]{2}{*}{$p$-value } \\
\hline & Isolation methods & \multicolumn{5}{|c|}{ DNA Concentration $(\mathrm{ng} / \mu \mathrm{L})$ (mean) } & \\
\hline \multirow[t]{3}{*}{$-80^{\circ} \mathrm{C}$} & Silica & 6.563 & 7.238 & 7.169 & 7.563 & 6.931 & 0.997 \\
\hline & Resin a & 7.944 & 10.488 & 10.000 & 9.938 & 9.539 & \\
\hline & Guanidine & 6.131 & 5.394 & 6.475 & 6.694 & 6.278 & \\
\hline \multirow[t]{3}{*}{$-20^{\circ} \mathrm{C}$} & Silica & 6.563 & 6.981 & 7.125 & 5.575 & 6.163 & 0.936 \\
\hline & Resin a & 46.470 & 91.585 & 81.920 & 60.350 & 60.650 & \\
\hline & Guanidine & 6.131 & 6.425 & 7.244 & 15.163 & 6.250 & \\
\hline \multirow[t]{3}{*}{$4^{0} \mathrm{C}$} & Silica & 6.563 & 8.744 & 8.481 & 8.225 & 7.575 & 0.781 \\
\hline & Resin a & 7.944 & 10.775 & 16.363 & 10.919 & 13.388 & \\
\hline & Guanidine & 6.131 & 7.363 & 7.338 & 6.213 & 5.881 & \\
\hline
\end{tabular}

Table 3. The purity of leptospira DNA stored in different temperatures

\begin{tabular}{|c|c|c|c|c|c|c|c|}
\hline Storage temperature & Shelf life (Days) & 1 & 14 & 28 & 43 & 91 & p-value \\
\hline & Isolation Procedure & & A 26 & 0 (mean) & & & \\
\hline \multirow[t]{3}{*}{$-80^{\circ} \mathrm{C}$} & Silica & 2.055 & 2.251 & 2.125 & 2.206 & 2.249 & 0.158 \\
\hline & Resin a & 1.851 & 1.627 & 1.684 & 1.706 & 1.740 & \\
\hline & Guanidine & 2.586 & 3.230 & 2.564 & 2.714 & 2.656 & \\
\hline \multirow[t]{3}{*}{$-20^{\circ} \mathrm{C}$} & Silica & 2.055 & 1.9825 & 1.916875 & 2.204375 & 2.325 & 0.035 \\
\hline & Resin a & 1.85125 & 1.51 & 1.51625 & 1.624375 & 1.815 & \\
\hline & Guanidine & 2.585625 & 2.288125 & 1.98625 & 2.285 & 3.045 & \\
\hline \multirow[t]{3}{*}{$4^{0} \mathrm{C}$} & Silica & 2.055 & 2.455 & 1.994375 & 2.159375 & 2.05125 & 0.356 \\
\hline & Resin a & 1.85125 & 1.611875 & 1.65875 & 1.735625 & 1.81625 & \\
\hline & Guanidine & 2.585625 & 2.55875 & 2.149375 & 2.464375 & 2.9525 & \\
\hline
\end{tabular}

Table 4. Leptospira's DNA copy number amplified by using real time PCR after stored in different temperatures

\begin{tabular}{|c|c|c|c|c|c|c|c|}
\hline \multirow[t]{2}{*}{ Storage temperature } & \multirow{2}{*}{$\begin{array}{l}\text { Shelf life (Day) } \\
\text { Isolation methods }\end{array}$} & \multirow[t]{2}{*}{1} & 14 & \multirow{2}{*}{$\frac{28}{\left.10^{3}\right)(\mathrm{me}}$} & \multirow[t]{2}{*}{43} & \multicolumn{2}{|c|}{$91 p$-value } \\
\hline & & & mplified & & & & \\
\hline \multirow[t]{3}{*}{$-80^{\circ} \mathrm{C}$} & Silica & 21,611 & 20,674 & 22,370 & 21,505 & 26,594 & 0.894 \\
\hline & Resin a & 50,167 & 57,816 & 50,327 & 55,209 & 62,734 & \\
\hline & Guanidine & 5,115 & 4,730 & 5,235 & 4,821 & 5,783 & \\
\hline \multirow[t]{3}{*}{$-20^{\circ} \mathrm{C}$} & Silica & 21,611 & 19,312 & 15,783 & 25,087 & 25,551 & 0.741 \\
\hline & Resin a & 50,167 & 51,732 & 51,536 & 54,119 & 40,369 & \\
\hline & Guanidine & 5,115 & 4,059 & 3,837 & 5,596 & 4,452 & \\
\hline \multirow[t]{3}{*}{$4^{0} \mathrm{C}$} & Silica & 21,611 & 27,852 & 33,282 & 30,057 & 29,838 & 0.621 \\
\hline & Resin a & 50,167 & 62,821 & 42,436 & 70,726 & 75,364 & \\
\hline & Guanidine & 5,115 & 5,084 & 6,143 & 6,722 & 5,708 & \\
\hline
\end{tabular}

\section{DISCUSSION}

The data showed that the resin method produced higher DNA concentration than the other two methods. However, the result also showed a wider standard deviation than the other DNA isolation methods. Previous research reported that DNA isolation result depends on the ability of researcher's handling procedures. ${ }^{16}$
Isolation with the resin resulted in a better purity although not significantly different. The mean value of DNA purity from resin methods showed an acceptable for further analysis. A ratio of OD A260/280 less than 1.8 is an indication of the presence of residual protein, phenol, or other reagents associated with the extraction protocol, where a ratio of more than 2.0 indicates RNA contamination. ${ }^{17}$ 
RNA contamination in DNA samples can cause low amplification in the sequencing cycle. Protein and organic solvent contamination will cause interference with the enzyme reaction. ${ }^{18}$

Storage temperature $\left(-80^{\circ},-20^{\circ}\right.$, and $\left.4^{\circ} \mathrm{C}\right)$ and shelf life did not give a significant effect on DNA quality from the first day until day 91 . This finding was similar to the result from Permenter et al. ${ }^{13}$ temperature $\left(4{ }^{\circ} \mathrm{C}\right.$ and room temperature, who found genomic DNA aliquots stored at $-20^{\circ} \mathrm{C}$ and $-80^{\circ} \mathrm{C}$ were stable for over 24 months. DNA samples stored at $4^{\circ} \mathrm{C}$ were stable for up to 12 months. The study by Ghatak et al. ${ }^{16}$ showed that the storage of extracted DNA from urine, blood, hair, and buccal swab at $-20^{\circ} \mathrm{C}$ over one month did not affect the PCR performance. It is important to remind that storage of the DNA extraction is better than storage of the fresh urine sample because Hilhorst et.al. (2013) showed that storage of fresh urine at $4^{\circ} \mathrm{C}$ or lower temperatures effected in significant degradation of human DNA. ${ }^{19}$

Urine is considered one of the specimens that can be used in Leptospira detection. Spiked urine is often representing the real urine from leptospirosis patients in Leptospira diagnosis. A study by Lee et $a l .{ }^{10}$ showed that lyophilized reagent-based PCR can detect Leptospira in spiked urine with as much as $1 \times 10^{2}$ Leptospira gene copies that come from $1 \times 10^{6}$ Leptospira/mL of spiked urine. The comparative study of three DNA extractions with plant proteinase by Veloso et al..$^{11}$ showed that cow urine contaminated with Leptospira as much as $10^{5}$ Leptospira / $\mathrm{mL}$ can be detected by PCR.

The amount of DNA in the sample should be known for further research purposes. Successful detection of Leptospira gene with PCR can be achieved when the DNA isolation sample has good quantity and quality. ${ }^{20}$ There are various methods that may be used to isolate DNA, but not all methods yield DNA with good quality and quantity. Guanidine isothiocyanate is the DNA extraction method that relies on the biochemical properties of the cellular component. The basic principle of this method is the separation between RNA, DNA and protein by an acidic solution, which yields high DNA purity and concentration. However, the procedure still uses hazardous chemicals like phenol and chloroform. The silica matrix method provides high-purity DNA and is easy to perform. The weakness of this procedure is the inability to recover the small fragments DNA that binds tightly with the silica matrix. Anion exchange matrix or anion exchange resin can extract high pure DNA compare to a silica matrix. However, it requires desalting of high salt concentration produced in the elution step. ${ }^{7}$

The use of q PCR is intended to identify and quantify the number of amplified products during a reaction. By using $\mathrm{qPCR}$, the number of starting templates can be determined. ${ }^{9}$ A recent study in Laos found that urine has no difference in sensitivity to blood, and urine is a useful sample for the molecular diagnosis of leptospirosis. ${ }^{6}$ In this study, $\mathrm{SecY}$ gene specific to Leptospira was used. The $\operatorname{Sec} Y$ gene is significantly better than the other housekeeping genes such as Lipl32 gene. ${ }^{15}$ The lowest Ct obtained in this study was DNA which was extracted using resin. It showed that Leptospira's DNA copy number which was obtained from resin methods remarkably highest among other methods. In addition, the lowest Ct may correspond to the good quality of template DNA extracted using resin. Furthermore, when we want to use clinical urine samples for doing DNA extraction, we need to aware of the sampling time post symptom onset because it may influence the quantity of the DNA for molecular determination. ${ }^{21}$

The limitation of this study was that we did not see the characteristics of the urine samples. Our suggestions for the future study is to provide the information of the urine-analysis conditions, such as macroscopic and sedimentation-microscopic characteristics, such as quantitative $\mathrm{pH}$, albumin, leucosit esterase, and other parameters that may influence the study.

In conclusion, DNA isolation using spin column chromatography with resin as separation matrix has the best quality and quantity based on the purity and concentration of DNA as well as the highest number of amplified $\mathrm{SecY}$ genes specific to Leptospira interrogans. Storage temperature at $4^{\circ},-20^{\circ}$, and $-80^{\circ} \mathrm{C}$ and life time of 91 days did not affect the quality and quantity of Leptospira DNA isolation products from spiked urine samples.

\section{Acknowledgment}

This work was supported under PEER Health grant Cycle 1 \#115, Sub-Grant Number: 2000004733 from USAID. We would like to thank USAID and the Institute for Vector and Reservoir Control Research and Development (IVRCRD), National Institute of Health Research and Development (NIHRD), The Ministry of Health Republic of Indonesia for all the support during the study. 


\section{Author contribution}

FDH is the coordinator and designer of the study, developing the concept and main contributor to the study. RAW carried out the experiment and wrote the manuscript under the direction of FDH. RR, MHG, and TW supervised the project and provided critical feedback with inputs to the manuscript.

\section{Conflict of interest}

The authors have no conflicts of interest to declare for this study.

\section{REFERENCES}

1. Haake DA, Levett PN. Leptospirosis in humans. Curr Top Microbiol Immunol [Internet]. 2015[cited 2018 Apr 5];387:65-97. Available from: http://www. ncbi.nlm.nih.gov/pubmed/25388133

2. Picardeau M. Virulence of the zoonotic agent of leptospirosis: still terra incognita? Vol. 15. Nature Reviews Microbiology. 2017:1-11

3. Budihal SV, Perwez K. Leptospirosis diagnosis: competancy of various laboratory tests. J Clin Diagnostic Res. 2014;8(1):199-202.

4. Bal AE, Gravekamp C, Hartskeerl RA, De MezaBrewster J, Korver H, Terpstra WJ. Detection of leptospires in urine by PCR for early diagnosis of leptospirosis. J Clin Microbiol. 1994;32(8):1894-8.

5. Journal I, Joshi M, Sciences M, Medicine C, Sciences M. Polymerase chain reaction : methods, principles and application. 2011;2(1).

6. Woods K, Nic-Fhogartaigh C, Arnold C, Boutthasavong L, Phuklia W, Lim C, et al. A comparison of two molecular methods for diagnosing leptospirosis from three different sample types in patients presenting with fever in Laos. Clin Microbiol Infect [Internet]. 2018[cited 2018 Sept 2];24(9):1017.e1-1017.e7. Available from: https:// doi.org/10.1016/j.cmi.2017.10.017

7. Ali N, Rampazzo RDCP, Costa ADiT, Krieger MA. Current nucleic acid extraction methods and their implications to point-of-care diagnostics. Biomed Res Int. 2017;2017:1-13

8. da Silva MAL, Medeiros Z, Soares CRP, da Silva ED, Miranda-Filho DB, de Melo FL. A comparison of four DNA extraction protocols for the analysis of urine from patients with visceral leishmaniasis. Rev Soc Bras Med Trop. 2014;47(2):193-7.

9. El Bali L, Diman A, Bernard A, Roosens NHC, Dekeersmaecker SCJ. Comparative study of seven commercial kits for human dna extraction from urine samples suitable for dna biomarker-based public health studies. J Biomol Tech. 2014;25(4):96-110.
10. Lee SV, Tai ES, Mutalib AR, Khairani-Bejo S, Bahaman AR. Rapid detection of pathogenic leptospires by lyophilized reagent-based Polymerase Chain Reaction. Trop Biomed. 2011;28(3):497-505.

11. Veloso IF, Lopes MTP, Salas CE, Moreira EC. A comparison of three DNA extractive procedures with leptospira for polymerase chain reaction analysis. Mem Inst Oswaldo Cruz. 2000;95(3):339-43.

12. Lucchesi PMA, Arroyo GH, Etcheverría AI, Parma $\mathrm{AE}$, Seijo AC. Recommendations for the detection of Leptospira in urine by PCR. Rev Soc Bras Med Trop. 2004;37(2):131-4.

13. Permenter J, Ishwar A, Rounsavall A, Smith M, Faske J, Sailey CJ, et al. Quantitative analysis of genomic DNA degradation in whole blood under various storage conditions for molecular diagnostic testing. Mol Cell Probes. 2015;29(6):449-53.

14. Schröder C, Steimer W. gDNA extraction yield and methylation status of blood samples are affected by longterm storage conditions. PLoS One. 2018;13(2):1-10.

15. Ahmed N, Manjulata Devi S, de los Á Valverde M, Vijayachari P, Machang'u RS, Ellis WA, et al. Multilocus sequence typing method for identification and genotypic classification of pathogenic Leptospira species. Ann Clin Microbiol Antimicrob. 2006;5(December). doi:10.1186/1476-0711-5- 28

16. Ghatak S, Muthukumaran RB, Nachimuthu SK. A simple method of genomic DNA extraction from human samples for PCR-RFLP analysis. J Biomol Tech. 2013;24(4):224-31.

17. Oxford Gene Technology (OGT). Understanding and measuring variations in DNA sample quality. Oxford Gene Technol Mol Genet Rev [Internet]. 2011;(August 2011)[cited 2018 July 3]:1-7. Available from: https:/www.ogt.com/resources/ literature/483_understanding_and_measuring variations_in_dna_sample_quality $\% 0 \mathrm{Ahttp}: / / \mathrm{www}$. ogt.co.uk/resources/literature/483 understanding and_measuring_variations_in_dna_sample_quality

18. Healthcare GE. Nucleic acid sample preparation for downstream analyses. Fed Eur Biochem Soc J [Internet]. 2009 [cited 2018 July 3;28-9624-00(10):1-171. Available from: http://www.ncbi.nlm.nih.gov/pubmed/11358530

19. Hilhorst $M$, Theunissen $R$, van Rie $H$, van Paassen $P$, Tervaert JWC. DNA extraction from long-term stored urine. BMC Nephrol [Internet]. 2013 [cited 2019 Febr 2];14(1):1. Available from: BMC Nephrology

20. Alberto A, Ramos N. DNA isolation by Chelex-100: an efficient approach to consider in leptospirosis early stages. J Coast Life Med. 2014; 2(6): 501-4.

21. Weiss S, Menezes A, Woods K, Chanthongthip A, Dittrich S, Opoku-Boateng A, et al. An extended multilocus sequence typing (MLST) scheme for rapid direct typing of leptospira from clinical samples. PLoS Negl Trop Dis. 2016;10(9):1-11. 